DOI:

УДК 669.245.018.044:620.193.53

С.В. Гайдук, д-р техн. наук, професор

О.А. Глотка, к. т. н, доцент

А.С. Дорогокупля, магістр

Запорізький національний технічний університет, м. Запоріжжя

\title{
МОДЕЛЮВАННЯ ТЕРМОДИНАМІЧНИХ ПРОЦЕСІВ ДЛЯ ОЦІНКИ ВПЛИВУ ТАНТАЛУ НА КРИТИЧНІ ТЕМПЕРАТУРИ І СТРУКТУРОУТВОРЕННЯ БАГАТОКОМПОНЕНТНИХ НІКЕЛЕВИХ СИСТЕМ
}

Методом комп'ютерного моделювання прочесів кристалізаиії (охолоджування) або нагріву, заснованого на розрахунковому методі CALPHAD, оиінений вилив танталу в дослідженому діапазоні легування від 1,0 до 5,0\% (за масою), порівняно з вихідним складом без танталу, на критичні температури багатокомпонентної системи $\mathrm{Ni}-13,5 \mathrm{Cr}-5 \mathrm{Co}-3,4 \mathrm{Al}-4,8 \mathrm{Ti}-7,3 \mathrm{~W}$ 0,8Mo-0,015B-0,03Y-0,01La-0,12C. Представлені результати розрахунків порівняно з експериментальними даними, отриманими на зразках тестових плавок методом диферениійного термічного аналізу (ДТА).

Ключові слова: ливарні жароміцні нікелеві сплави; система легування; критичні температури; ліквідус; солідус; інтервал кристалізації; структура; термічна обробка.

The effect of tantalum in the investigated doping range from 1.0 to $5.0 \%$ (by weight), compared to the initial composition without tantalum, on the critical temperatures of multicomponent is estimated by computer simulation of crystallization (cooling) or heating, based on the calculation method CALPHAD systems (Ni-13.5Cr-5Co-3,4Al-4,8Ti-7,3W-0,8Mo-0,015B-0,03Y-0,01La-0,12C). The results of calculations are presented in comparison with experimental data obtained on samples of test heats by the method of differential thermal analysis (DTA).

Keywords: casting heat-resistant nickel alloys; doping system; critical temperatures; liquidus; solidus; crystallization interval; structure; heat treatment.

\section{Постановка проблеми}

В даний час підвищення надійності роботи матеріалів газових турбін і збільшення експлуатаційного ресурсу деталей з них, здійснюється двома основними напрямками. Перший напрямок - заміна існуючих промислових жароміцних нікелевих сплавів на розроблені нові сплави. Другий напрямок - модернізація хімічного складу відомих промислових сплавів шляхом легування перспективними елементами, наприклад танталом, 3 оптимізацією його меж легування всередині марки. В результаті модернізовані склади, сплави нового покоління, забезпечать підвищення комплексу службових характеристик сплаву, а отже, ресурсу робочих лопаток наземних газоперекачувальних установок в умовах тривалого впливу високих температур і напружень в агресивному середовищі $[1-5]$.

Міжнародна практика показує, що в умовах загальної світової кризи другий напрямок економічно більш актуальний і має широкі перспективи, так як не вимагає тривалого часу на об'ємні наукові і технологічні дослідження, при цьому немає необхідності у великих обсягах промислових і фінансових ресурсів, в порівнянні з першим напрямком. Сучасний підхід до легування ливарних жароміцних нікелевих сплавів перспективними елементами приводить до компромісу, який повинен одночасно враховувати вплив даних елементів як на характеристики міцності, корозійну стійкість, структурну стабільність, з одного боку, так і технологічність, а також економічну доцільність, з іншого [3-6].

У багатьох дослідженнях відзначається про позитивний вплив танталу на характеристики міцності і термічну стабільність фаз в ливарних жароміцних нікелевих сплавах. При цьому наголошується, що в межах марочного складу для різних складнолегованих систем жароміцних нікелевих сплавів, оптимальні межі легування для нового елементу, що вводиться $є$ індивідуальними $[1-6]$. 
У даній роботі за допомогою комп'ютерного моделювання, заснованого на розрахунковому методі CALPHAD в програмі JMatPro [7] було оцінено вплив легування танталом в дослідженому діапазоні від 1,0 до 5,0\% 3 концентраційним кроком $1 \%$ за масою на критичні температури фазових перетворень в багатокомпонентній нікелевій системі Ni-13,5Cr-5Co-3,4Al4,8Ti-7,3W-0,8Mo-0,015B-0,03Y-0,01La-0,12C (сплав 3МI-3У середнього рівня легування). Мета - визначення оптимального вмісту танталу для підвищення рівня температурних і механічних властивостей матеріалу.

В даний час по теорії легування багатокомпонентних нікелевих систем опубліковано досить велику кількість робіт $[1-6,8]$, однак недостатньо висвітлюються питання, які пов'язані з індивідуальною оцінкою впливу окремих легувальних елементів на критичні температури розчинення або виділення окремих фаз в таких системах. Тому дана область досліджень актуальна для розвитку теорії легування як при розробці нових сплавів, так і удосконаленню складів відомих промислових марок жароміцних нікелевих сплавів з метою поліпшення комплексу службових характеристик для конкретних умов експлуатації.

\section{Формулювання мети дослідження}

Метою цієї роботи є порівняльна оцінка впливу танталу на критичні температури виділення і розчинення фаз в багатокомпонентної системі Ni-13,5Cr-5Co-3,4Al-4,8Ti-7,3W-0,8Mo0,015B-0,03Y-0,01La-0,12C за допомогою пасивного експерименту розрахунковим методом CALPHAD і активного експерименту методом диференційного термічного аналізу (ДТА).

Метод пасивного експерименту полягає в комп'ютерному моделюванні термодинамічних процесів, що протікають при кристалізації (охолодженні) або нагріванні в сплавах [1014]. Комп'ютерне моделювання даних процесів дозволяє провести розрахункове прогнозування і провести порівняльну оцінку впливу танталу на критичні температури виділення або розчинення окремих фаз в дослідних складах, в порівнянні з базовим складом без танталу. Розрахунки критичних температур проводили індивідуально по кожному дослідженому складу при покроковому введенні танталу (Та) в фіксований склад багатокомпонентної системи, наведеної вище, 3 концентраційним кроком $1,0 \%$ в досліджуваному діапазоні $(1,0-5,0 \%$ за масою). В новій системі багатокомпонентного легування (Ni-Cr-Co-Al-Ti-Mo-W-Ta-B-Y-La-C), що відповідає марочному сплаву ЗМІ-3У середнього рівня легування, діапазон варіювання новим елементом танталом був заданий в досліджуваних межах $(1,0 \ldots 5,0)$ \% за масою (табл. 1).

Таблиия 1. Хімічний склад сплаву ЗМІ-3У, легованого танталом

\begin{tabular}{|c|c|c|c|c|c|c|c|c|c|c|c|}
\hline \multirow{2}{*}{$\begin{array}{c}\text { № } \\
\text { складу }\end{array}$} & $\mathrm{C}$ & $\mathrm{Cr}$ & $\mathrm{Co}$ & $\mathrm{Al}$ & $\mathrm{Ti}$ & $\mathrm{Mo}$ & $\mathrm{W}$ & $\boldsymbol{T a}$ & $\mathrm{B}$ & Y & La \\
\hline ЗМІ-3У & 0,12 & 13,5 & 5,0 & 3,4 & 4,8 & 0,8 & 7,3 & $\mathbf{0 , 0}$ & 0,015 & 0,03 & 0,01 \\
\hline 1 & 0,12 & 13,5 & 5,0 & 3,4 & 4,8 & 0,8 & 7,3 & $\mathbf{1 , 0}$ & 0,015 & 0,03 & 0,01 \\
\hline 2 & 0,12 & 13,5 & 5,0 & 3,4 & 4,8 & 0,8 & 7,3 & $\mathbf{2 , 0}$ & 0,015 & 0,03 & 0,01 \\
\hline 3 & 0,12 & 13,5 & 5,0 & 3,4 & 4,8 & 0,8 & 7,3 & $\mathbf{3 , 0}$ & 0,015 & 0,03 & 0,01 \\
\hline 4 & 0,12 & 13,5 & 5,0 & 3,4 & 4,8 & 0,8 & 7,3 & $\mathbf{4 , 0}$ & 0,015 & 0,03 & 0,01 \\
\hline 5 & 0,12 & 13,5 & 5,0 & 3,4 & 4,8 & 0,8 & 7,3 & $\mathbf{5 , 0}$ & 0,015 & 0,03 & 0,01 \\
\hline
\end{tabular}

Ефективність розрахункового методу CALPHAD полягає в досить швидкому отриманні інформації, якої бракує, заснованої на надійних принципах фізичного матеріалознавства, і має ряд значних переваг, в порівнянні з методами математичної статистики: кореляційним, дисперсійним, регресійним аналізами. Розрахунки методом CALPHAD, які отримано шляхом комп'ютерного моделювання процесів кристалізації (охолодження) або нагрівання, дозволяють без багаторазових проміжних прямих експериментів визначати критичні температури виділення або розчинення окремих фаз, а також температурні інтервали фазових перетворень, в залежності від вмісту танталу в досліджуваному діапазоні легування для наведеної вище складнолегованої системи на основі нікелю. Результати розрахунків CALPHAD-методом порівнювалися 3 даними активного експерименту, отриманими методом ДТА на зразках тестових плавок. 


\section{Виклад основного матеріалу}

При охолодженні (кристалізації) або нагріванні в багатокомпонентних жароміцних нікелевих сплавах протікає ряд фазових перетворень, що визначають фазовий склад і кінцеву структуру. В цілому, хімічний склад зумовлює температурні інтервали протікання основних фазових перетворень при кристалізації (охолодженні) або нагріванні, до яких відносяться розчинення або виділення часток $\gamma^{\prime}$ - фази в $\gamma$ - твердому розчині, розчинення або плавлення нерівноважної евтектики $\left(\gamma+\gamma^{\prime}\right)$, плавлення $\gamma$ - твердого розчину, виділення або розчинення карбідів різного типу $[9,15,16]$.

До негативних структурних змін можуть призводити несприятливі фазові перетворення, що ведуть до зниження службових властивостей і втрати працездатності сплаву. Дані процеси можливі в багатокомпонентних жароміцних нікелевих сплавах при незбалансованому хімічному складі $[17,18]$.

Моделювання процесу кристалізації (охолодження) або нагріву здійснювали в температурному діапазоні $\left(20^{\circ} \ldots 1400^{\circ} \mathrm{C}\right)$ з одночасним проведенням термодинамічних розрахунків із визначенням впливу танталу в досліджених межах ( $1-5 \%$ за масою) на критичні температури фазових перетворень в сплаві ЗМІ-3У середнього рівня легування. Прийнято вважати, що в процесі кристалізації всі основні фази виділяються в структурі ливарних жароміцних нікелевих сплавів до температури $\mathrm{t}=600^{\circ} \mathrm{C}$ (рис. 1 ).

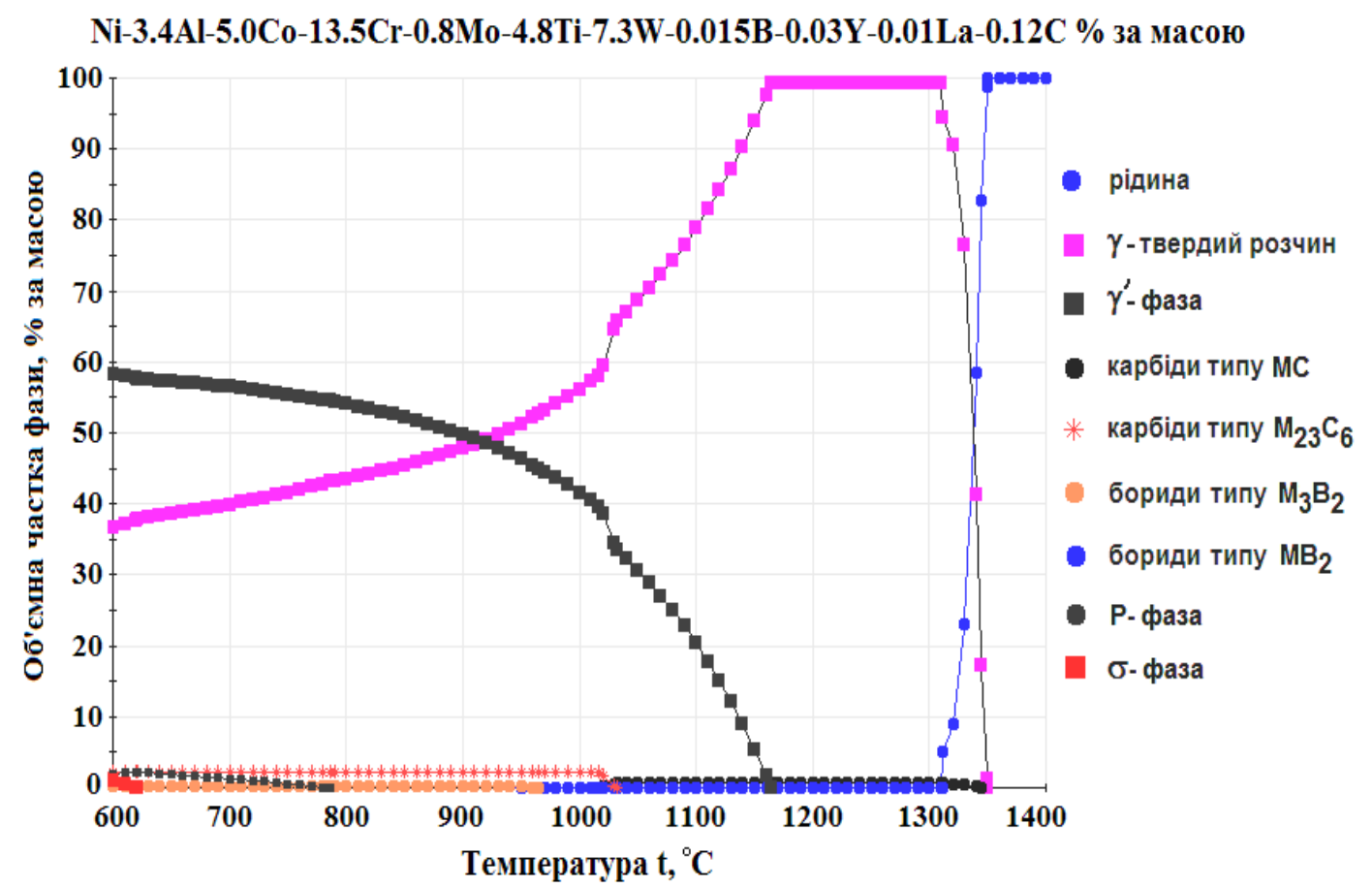

Puc. 1. Моделювання процесу виділення фаз при кристалізації в структурі сплаву ЗМІ-3У середнього рівня легування

На рис. 1 і в табл. 1 представлені результати розрахунків, отримані за визначенням критичних температур в процесі кристалізації (охолодження), а також нагріву вихідного складу без танталу і складів з танталом в дослідженому діапазоні легування. Даний підхід дозволив без проведення попередніх прямих експериментів отримати залежність основних критичних температур від вмісту танталу в дослідженому діапазоні для конкретної багатокомпонентної системи: температуру повного розплавлення ліквідуса $-\left(\mathrm{t}_{\mathrm{L}}\right)$; температуру плавлення $\gamma$ - твердого розчину солидуса $-\left(\mathrm{t}_{\mathrm{S}}\right)$; температуру локального плавлення евтектики $\left(\gamma+\gamma^{\prime}\right)-\left(\mathrm{t}_{\mathrm{EBT}}\right)$; температурний інтервал кристалізації - $\left(\Delta \mathrm{t}_{\mathrm{KP} .}\right)$; температуру початку розчинення $\gamma^{\prime}-$ фази $-\left(\mathrm{t}_{\text {п.Р. }} \gamma^{\prime}\right)$; температуру кінця розчинення $\gamma^{\prime}-$ фази - $\left(\mathrm{t}_{\text {к.P. }}{ }^{\prime}\right)$; температурний інтервал для проведення гомо- 
генізації, термічної обробки на $\gamma$ - твердий розчин $-\left(\Delta \mathrm{t}_{\text {гом. }}\right)$.

Аналіз результатів, представлених в табл. 2, показує, що з підвищенням вмісту танталу в дослідженому діапазоні легування, критичні температури ліквідуса $\left(\mathrm{t}_{\mathrm{L}}\right)$ i солідуса $\left(\mathrm{t}_{\mathrm{S}}\right)$ поступового знижуються. Одночасно звужується температурний інтервал кристалізації ( $\mathrm{t}_{\mathrm{\kappa P}}$.) сплавів, що позитивно впливає на технологічні властивості сплаву при отриманні виливків зі спрямованою або монокристалічною структурою. Так, температура ліквідуса $\left(\mathrm{t}_{\mathrm{L}}\right)$ при вмісті танталу $5,0 \%$ за масою знизилася на $26^{\circ} \mathrm{C}$, а температура солидуса $\left(\mathrm{t}_{\mathrm{s}}\right)$ знизилася тільки на $14^{\circ} \mathrm{C}$, в порівнянні з цими температурами для базового складу ЗМІ-3У без танталу. При цьому, підвищилася температура ( $\mathrm{t}_{\mathrm{EB}}$.) локального плавлення $\left(\gamma+\gamma^{\prime}\right)$ евтектики на $37^{\circ} \mathrm{C}$ (табл. 2$)$.

Таблиия 2. Розрахункові значення критичних температур для багатокомпонентної системи (Ni-13,5Cr-5Co-3,4Al-4,8Ti-7,3W-0,8Mo-0,015B-0,03Y-0,01La-0,12C), легованої танталом

\begin{tabular}{|c|c|c|c|c|c|c|c|c|}
\hline \multirow{2}{*}{$\begin{array}{c}\text { № } \\
\text { складу }\end{array}$} & \multicolumn{7}{|c|}{ Температурні характеристики, ${ }^{\circ} \mathrm{C}$} \\
\cline { 2 - 9 } & $\mathrm{t}_{\mathrm{L}}$ & $\mathrm{t}_{\mathrm{S}}$ & $\mathrm{t}_{\text {Евт. }}$ & $\mathrm{t}_{\text {п.Р. }} .^{\prime^{\prime}}$ & $\mathrm{t}_{\text {К.P. }}{ }^{\gamma^{\prime}}$ & $\Delta \mathrm{t}_{\text {КР. }}$ & $\Delta \mathrm{t}_{\text {Гом. }}$ & $\mathrm{t}_{\text {Гом. }}$ \\
\hline 3МI-3У & 1350,4 & 1290,0 & 1233,0 & 843,1 & 1162,4 & 60,4 & 70,6 & 1180 \\
\hline 1 & 1344,9 & 1288,0 & 1239,0 & 846,3 & 1162,9 & 56,9 & 76,1 & 1195 \\
\hline 2 & 1340,0 & 1285,0 & 1245,0 & 849,4 & 1163,8 & 55,0 & 81,2 & 1210 \\
\hline 3 & 1334,0 & 1283,0 & 1250,0 & 852,8 & 1164,9 & 51,0 & 85,1 & 1225 \\
\hline 4 & 1329,3 & 1280,3 & 1265,0 & 855,1 & 1170,0 & 49,1 & 95,0 & 1240 \\
\hline 5 & 1324,4 & 1276,0 & 1270,0 & 858,2 & 1175,0 & 48,4 & 95,0 & 1255 \\
\hline
\end{tabular}

В табл. 2 показано, що в складі «0» (ЗМІ-3У без танталу) температури початку розчинення $\left(\mathrm{t}_{\text {п.Р. }}{ }^{\gamma^{\prime}}\right)$ і кінця розчинення $\left(\mathrm{t}_{\text {K.Р. }}{ }^{\gamma^{\prime}}\right) \gamma^{\prime}$ - фази складають $\left(\sim 843^{\circ} \mathrm{C}\right) \mathrm{i}\left(\sim 1162^{\circ} \mathrm{C}\right)$, відповідно. Ці температури поступово підвищуються і для дослідженого складу «5» 3 5,0 \% танталу складають $\left(\sim 858^{\circ} \mathrm{C}\right)$ і $\left(\sim 1175^{\circ} \mathrm{C}\right)$ відповідно, що позитивно впливає на термічну фазову стабільність.

Легування танталом позитивно впливає на температурний інтервал $\left(\Delta \mathrm{t}_{\Gamma о м}\right)$ для проведення ефективної термічної обробки (гомогенізації), розширює його на $\sim 25^{\circ} \mathrm{C}$. Відомо, що температурний інтервал $\left(\Delta \mathrm{t}_{\text {Гом. }}\right)$ не повинен бути менше, ніж $\Delta \mathrm{t}_{\text {Гом. }}=\left(\mathrm{t}_{\mathrm{EBT} .}-\mathrm{t}_{\text {К.Р. }}{ }^{\gamma^{\prime}}\right) \geq 20^{\circ} \mathrm{C}$ (див. табл. 2).

Аналіз отриманих результатів дозволив зробити висновок про те, що з підвищенням

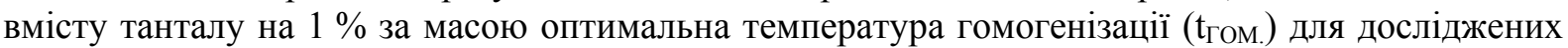
складів підвищується в середньому на $15^{\circ} \mathrm{C}$.

Експериментальні дослідження проводили методом диференційного термічного аналізу (ДТА) на установці ВДТА-8М в середовищі гелію при постійній швидкості нагрівання та охолодження на рівні $80^{\circ} \mathrm{C} /$ хв. За еталон використовували термічно інертний зразок чистого вольфраму (W-еталон). За допомогою методу ДТА виявлялися перетворення, як в твердому, так і в рідкому стані, які пов'язані зі зміною ентальпії в зразку. Зі зміною температури в часі порівнювали теплові потоки в термічно інертному еталоні (W) і досліджуваному зразку. У разі їх рівності отримували базову лінію на реєструючому приладі без будь-яких змін. При наявності в досліджуваному зразку будь-яких перетворень, пов'язаних з поглинанням або виділенням тепла (ендо- та екзо- термічні процеси відповідно), фіксували відхилення від прямолінійного ходу базової лінії у вигляді піків на термічної кривої в одну або іншу сторону. За кількістю, формою, величиною і розташуванням цих піків на термічної кривої отримували дані по граничним значенням температурних процесів, які протікають, тобто визначали критичні температури досліджуваних складів. Розшифровка термограм, отриманих в ході експериментів, проводили з урахуванням рекомендацій, зазначених в роботах $[8,9]$.

Максимальна температура нагріву зразків $1450^{\circ} \mathrm{C}$ в установці ВДТА-8П. Заповнення камери гелієм до $0,8-0,9$ ат. проводилося після отримання розрідження не менше $10-5$ мм. рт. ст. При цьому операцію «промивання» гелієм повторювали двічі. Зразки досліджуваних сплавів мали однаковий розмір (діаметр $\mathrm{d}=3$ мм; довжина $1=3$ мм) і масу $(\sim 1,45$ г). Відповідно до методики експерименту кристалізацію (охолодження) і нагрів кожного зразка проводили двічі в тиглі з оксиду цирконію. 
При аналізі експериментальних даних на ДТА - кривих було підтверджено, що 3 підвищенням концентрації танталу в дослідженому діапазоні (1-5\%) в дослідних складах оптимальна температура гомогенізації першого ступеня зміщується на $\sim 15^{\circ} \mathrm{C}$ до області більш високих температур. Гомогенізація нижче температури $\left(\mathrm{t}_{\mathrm{EBT}}\right)$ евтектичних перетворень і вище температури $\left.\left(\mathrm{t}_{\text {к.P. }}\right)^{\prime}\right)$ кінця розчинення $\gamma^{\prime}-$ фази забезпечує в структурі дослідних складів утворення більш гомогенного $\gamma$ - твердого розчину.

У табл. 2 і 3 показано, що температурний інтервал для проведення оптимальної гомогенізації дослідним складам $(0-5)$ знаходиться в діапазоні $\left(1180-1255^{\circ} \mathrm{C}\right)$ з температурним кроком $15^{\circ} \mathrm{C}$, відповідно.

Таблиия 3. Режими термообробки для дослідних складів

\begin{tabular}{|c|c|c|c|c|c|}
\hline $\begin{array}{c}\text { № } \\
\text { складу }\end{array}$ & $\begin{array}{c}\mathrm{t}^{\mathrm{I}} \text { гом., } \\
{ }^{\circ} \mathrm{C}\end{array}$ & $\begin{array}{c}\text { Час } \\
\text { витримки, } \Gamma\end{array}$ & $\begin{array}{c}\mathrm{t}^{\mathrm{II}} \text { гом., } \\
{ }^{\circ} \mathrm{C}\end{array}$ & $\begin{array}{c}\text { Час } \\
\text { витримки, } \Gamma\end{array}$ & $\begin{array}{c}\text { Умови охолодження } \\
\text { між ступенями }\end{array}$ \\
\hline 0 & 1180 & 4 & 1050 & 4 & на повітрі \\
\hline 1 & 1195 & 4 & 1050 & 4 & на повітрі \\
\hline 2 & 1210 & 4 & 1050 & 4 & на повітрі \\
\hline 3 & 1225 & 4 & 1050 & 4 & на повітрі \\
\hline 4 & 1240 & 4 & 1050 & 4 & на повітрі \\
\hline 5 & 1255 & 4 & 1050 & 4 & на повітрі \\
\hline
\end{tabular}

Металографічні дослідження показали, що мікроструктура монокристалічних зразків дослідних складів (0-5), отриманих за серійною технологією, з кристалографічною орієнтацією (КГО) [001] в литому стані має типово дендритну будову, що виявляється в нерівномірному розподілі часток $\gamma^{\prime}-$ фази, евтектики $\left(\gamma+\gamma^{\prime}\right)$ і карбідної фази (рис. 2$)$.

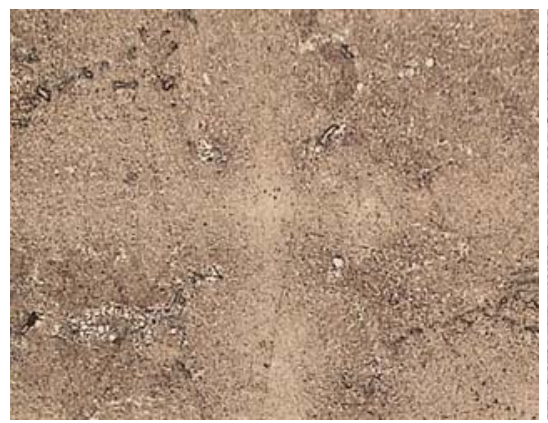

$\mathrm{a}$

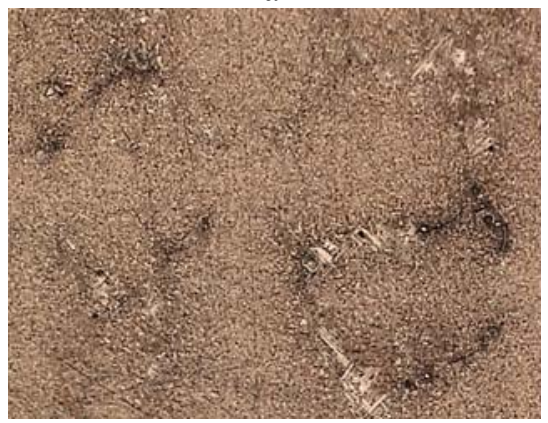

$\Gamma$

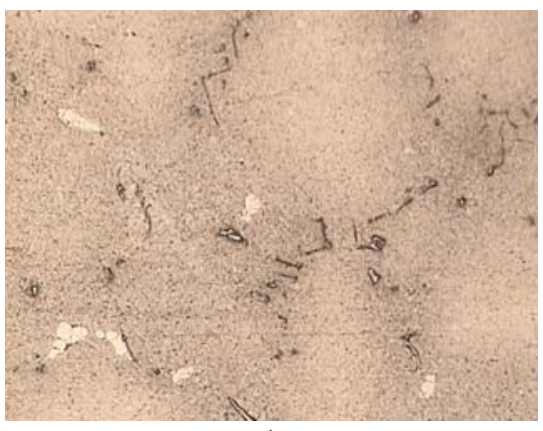

6

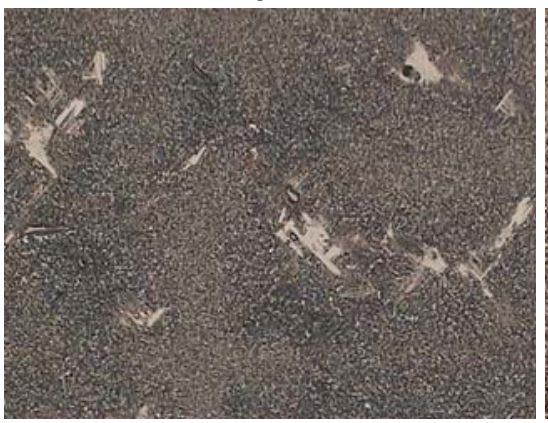

Д

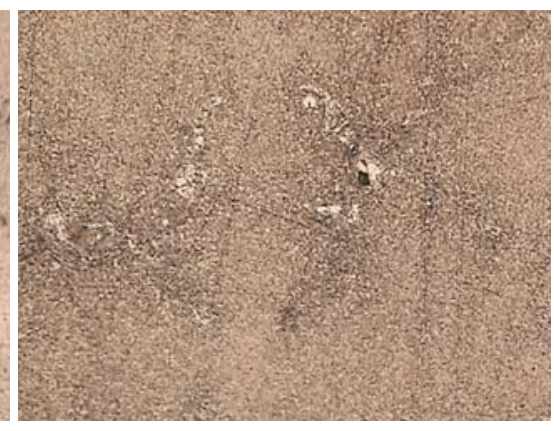

B

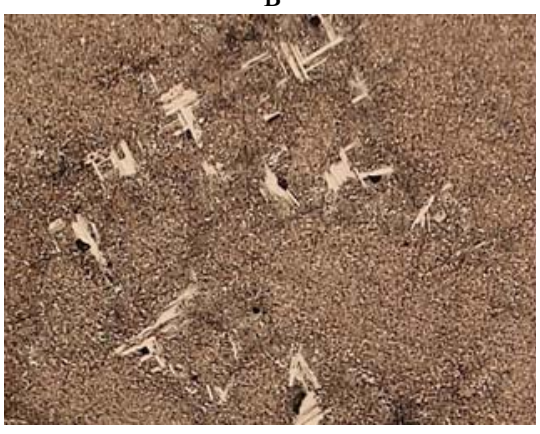

e

a - 3MI-3У без Тa;

$\Gamma-3 \mathrm{MI}-3 \mathrm{Y}+3,0 \% \mathrm{Ta}$;

$6-3 \mathrm{MI}-3 \mathrm{Y}+1,0 \% \mathrm{Ta}$

д - 3MI-3У $+4,0 \%$ Ta;

в - 3MI-3У $+2,0 \%$ Ta;

$\mathrm{e}-3 \mathrm{MI}-3 \mathrm{Y}+5,0 \%$ Ta.

Puc. 2. Дендритна структура дослідних складів в литому стані: $\times 200$ 
У міждендритних областях розташовані виділення метастабільної нерівноважної евтектики $\left(\gamma+\gamma^{\prime}\right)$, які мають морфологію від віялообразної (рис. 2 а, б, в) до пластинчастої (рис. 2 г, д, е).

Після кристалізації в структурі досліджених складів спостерігається утворення карбідів типу МеС поблизу великих виділень евтектики $\left(\gamma+\gamma^{\prime}\right)$, які частково заповнюють простір між гілками дендритів. Металографічний аналіз показав, що, в порівнянні зі сплавом ЗМІ-3У без танталу, при вмісті танталу 5,0\% (склад «5») підвищується об'ємна частка $\left(\mathrm{V}_{\gamma^{\prime}}\right) \gamma^{\prime}-$ фази на $8-10 \%$, евтектики $\left(\gamma+\gamma^{\prime}\right)$ на 3-5\%.

На рис. 3 видно, що після кристалізації в структурі дослідних складів частки $\gamma^{\prime}-$ фази виділилися з $\gamma$ - твердого розчину рівномірно і мають правильну кубічну і прямокутну морфологію, за виключенням складу «5» (рис. 3 е) де спостерігається неоднорідна структура.
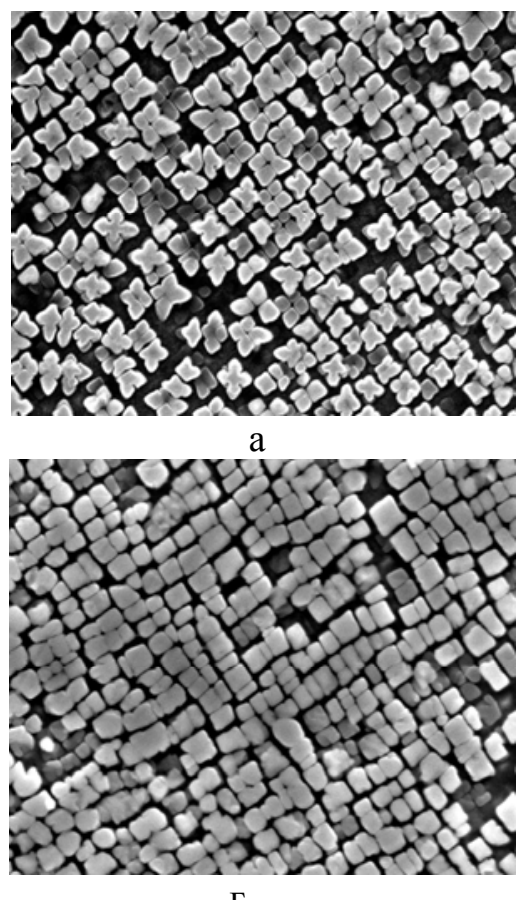

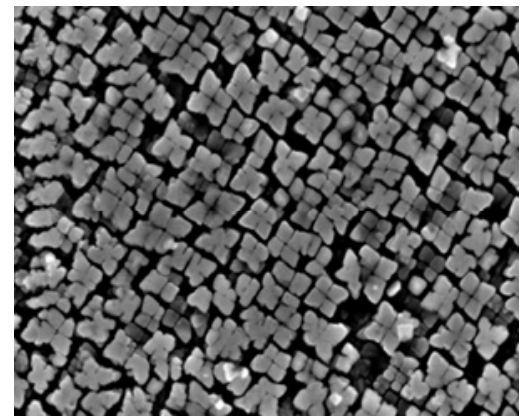

б

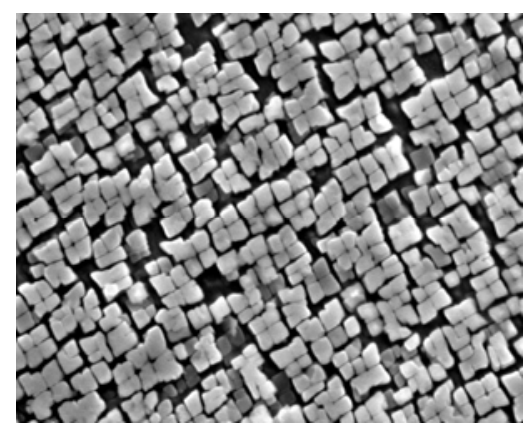

Д
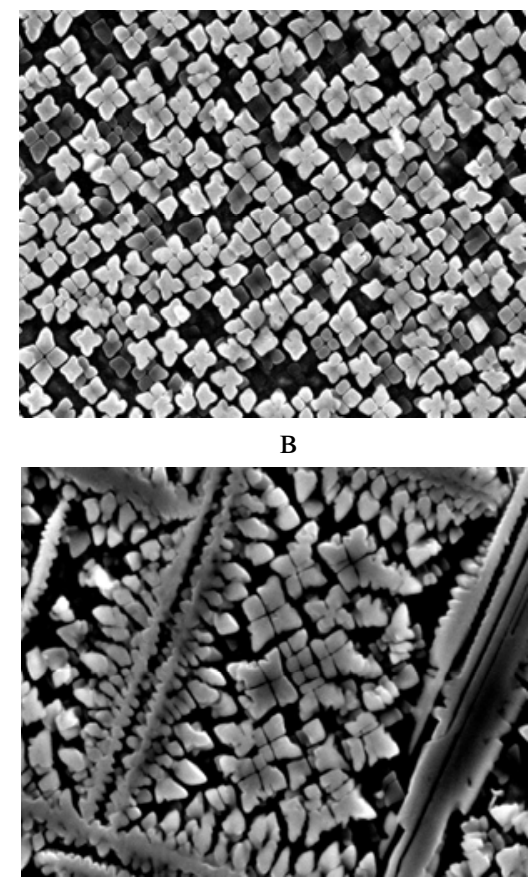

e

a-3MI-3У без Та;

$6-3 \mathrm{MI}-3 \mathrm{Y}+1,0 \% \mathrm{Ta}$;

в $-3 \mathrm{MI}-3 \mathrm{Y}+2,0 \% \mathrm{Ta}$;

$$
\begin{aligned}
& \text { г-3МI-3У + 3,0\% Та; } \\
& \text { д-3МI-3У + 4,0\% Та; } \\
& \text { e-3MI-3У }+5,0 \% \text { Та. }
\end{aligned}
$$

Рuc. 3. Розподіл $\gamma^{\prime}$ - фази в структурі дослідних складів в литому стані: $\times 10000$

На рис. 4 представлено розподіл $\gamma^{\prime}$ - фази в структурі дослідних складів після двоступеневої гомогенізації (див. табл. 3). Слід зазначити, що другий ступінь гомогенізації був обраний, враховуючи технологічну температуру нанесення захисного покриття і проводився всім дослідним складам за температури $\mathrm{t}=1050^{\circ} \mathrm{C}$.

Після проведення двохступеневої термообробки в структурі досліджених складів помітно знижується кількість нерівноважних фаз. 3 підвищенням концентрації танталу в сплаві 3МІ3У з 1,0 \% до 5,0\%, за масою, в структурі збільшується об'ємна кількість дрібнодисперсних частинок $\gamma^{\prime}$ - фази, в порівнянні зі сплавом ЗМІ-3У без танталу. 


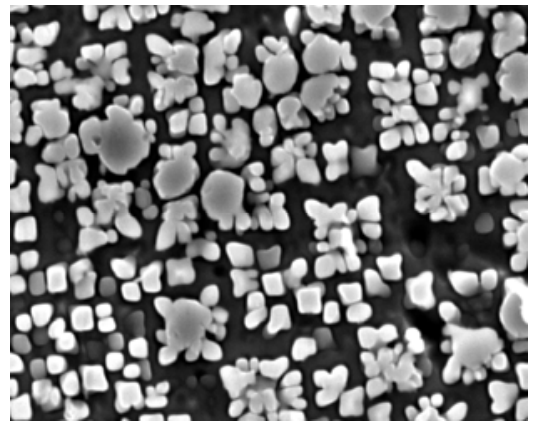

a

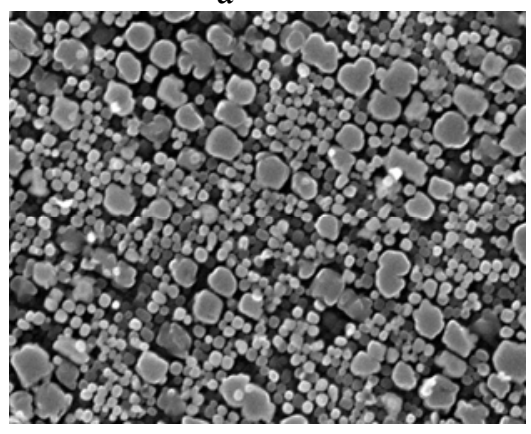

$\Gamma$

a - 3MI-3У без Та;

$6-3 \mathrm{MI}-3 \mathrm{Y}+1,0 \% \mathrm{Ta}$;

в - 3MI-3 $\mathrm{Y}+2,0 \% \mathrm{Ta}$;

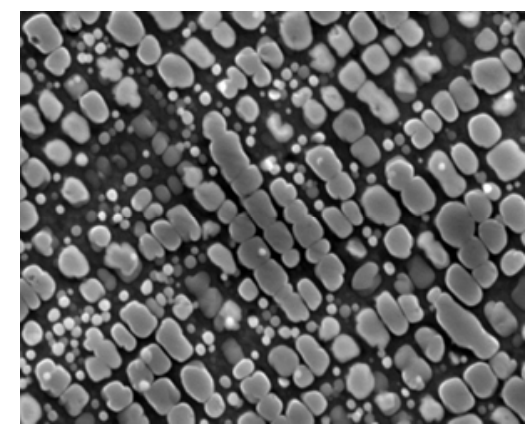

6

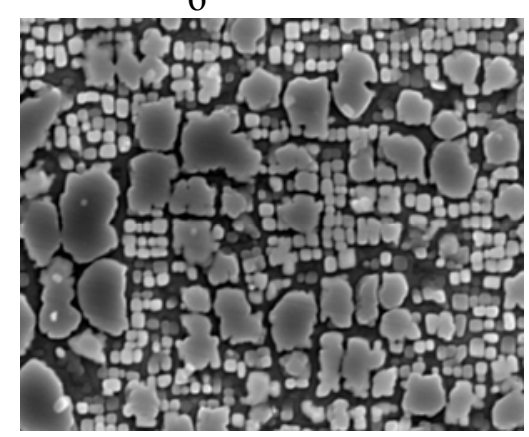

д

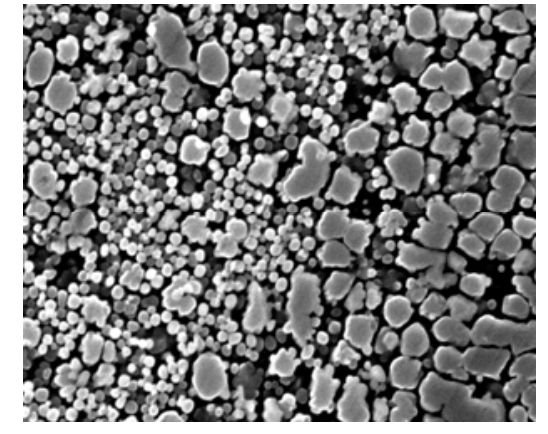

B

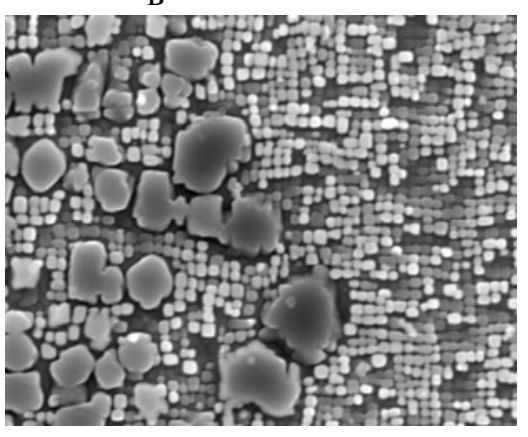

e

$$
\begin{aligned}
& \text { г-3МI-3У + 3,0\% Та; } \\
& \text { д-3MI-3У + 4,0\% Та; } \\
& \text { e-3MI-3У + 5,0\% Тa. }
\end{aligned}
$$

Рис. 4. Розподіл $\gamma^{\prime}$ - фази в структурі дослідних складів після двох ступеневої термообробки: $\times 10000$

Порівняльний візуальний аналіз показав, що в процесі другого ступеня гомогенізації при $\mathrm{t}=1050^{\circ} \mathrm{C}$ в структурі дослідних складів спостерігається коагуляція часток $\gamma^{\prime}$ - фази, які не розчинилися. Одночасно відбувається додаткове виділення дрібнодисперсних частинок $\gamma^{\prime}-$ фази в результаті дорозпаду $\gamma$ - твердого розчину, що формує іiї бімодальність (двох розмірність). Після проведення другого ступеня гомогенізації частки $\gamma^{\prime}$ - фази втрачають правильну кубічну форму. У термообробленому стані в структурі дослідних складів формується бімодальність часток $\gamma^{\prime}$ - фази за розміром. Таким чином, після двоступеневої гомогенізації в структурі дослідних складів значно зменшилася кількість метастабільних фаз, сформована більш гомогенна і стабільна структура.

\section{Висновки}

1. Розрахунки, які отримані CALPHAD-методом, дозволяють на початковій стадії дослідження ефективно прогнозувати температурні характеристики, а також оптимізувати режими термічної обробки для отримання стабільної структури без попереднього проведення прямих експериментів. Результати розрахунку критичних температур добре узгоджуються 3 даними експериментів, отриманих методом ДТА на монокристалічних зразках [001] тестових плавок.

2. Для багатокомпонентної системи (Ni-13,5Cr-5Co-3,4Al-4,8Ti-7,3W-0,8Mo-0,015B$0,03 \mathrm{Y}-0,01 \mathrm{La}-0,12 \mathrm{C})$ вміст танталу до $4,0 \%$ за масою оцінюється як позитивний. Збільшення вмісту танталу до 5,0 \% за масою призводить до помітного зниження температури солідуса $\left(\mathrm{t}_{\mathrm{s}}\right)$, нижче, ніж $1280^{\circ} \mathrm{C}$, що $є$ небажаним для ливарних жароміцних нікелевих сплавів, які працюють за температур до $1000^{\circ} \mathrm{C}$ і вище.

3. Вміст танталу 5,0 \% за масою для дослідженої багатокомпонентної системи оцінюється як негативний, оскільки перелегування танталом може призводити до таких небажаних наслідків, як збільшення структурної неоднорідності і зниження фазової стабільності за раху- 
нок виділення шкідливих ТЩУ- фаз несприятливої морфології, що може призводити до різкого зниження міцності, пластичності і втрати працездатності матеріалу.

\section{Список використаної літератури}

1. Каблов Е. Н. Литейные жаропрочные сплавы. Эффект С. Т. Кишкина : науч.-техн. сб. : к 100летию со дня рождения С. Т. Кишкина / Под общ. ред. Е. Н. Каблова. - М. : Наука, 2006. $272 \mathrm{c}$.

2. Каблов Е. Н. Литые лопатки газотурбинных двигателей (сплавы, технология, покрытия) / Е. Н. Каблов. - Всероссийский научно-исследовательский институт авиационных материалов, Государственный научный центр Российской Федерации. - М. : МИСИС, 2001. - 632 с.

3. Патон Б. Е. Жаропрочность литейных никелевых сплавов и защита их от окисления / Б. Е. Патон, Г. Б. Строганов, С. Т. Кишкин и др. - К. : Наук. думка, 1987. -256 с.

4. Кишкин С. Т. Литейные жаропрочные сплавы на никелевой основе / Кишкин С. Т., Строганов Г. Б., Логунов А. В. - М. : Машиностроение, 1987. - 116 с.

5. Котсорадис Д. Жаропрочные сплавы для газовых турбин. Материалы международной конференции / Д. Котсорадис, П. Феликс, Х. Фишмайстер и др. ; пер. с англ. под ред. Р. Е. Шалина. - М. : Металлургия, 1981. -480 с.

6. Симс Ч. Т. Суперсплавы II. Жаропрочные материалы для аэрокосмических и промышленных энергоустановок / Ч. Т. Симс, Н. С. Столофф, У. К. Хагель ; пер. с англ. под ред. Р. Е. Шалина. - М. : Металлургия, 1995. - Кн. 1, 2. - 384 с.

7. Saunders N. The Application of CALPHAD Calculations to Ni-Based Superalloys / N. Saunders, M. Fahrmann, C. J. Small // In «Superalloys 2000» eds. K.A. Green, T. M. Pollock and R.D. Kissinger. - TMS. - Warrendale. $-2000 .-803$ p.

8. Fippen J. S. Using differential thermal analysis to determine phase change temperatures / J. S. Fippen, P. B. Sparks // Metal Progr. - 1979. - № 4. - P. 56-59.

9. Вертоградский В. А. Исследование фазовых превращений в сплавах типа ЖС методом ДТА / В. А. Вертоградский, Т. П. Рыкова // Жаропрочные и жаростойкие стали и сплавы на никелевой основе. - М. : Наука, 1984. - С. 223-227.

10. Попов В. В. Анализ растворимости карбидов, нитридов и карбонитридов в сталях методами компьютерной термодинамики. І. Описание термодинамических свойств. Метод расчета / В. В. Попов, И.И. Горбачев // Физика металлов и металловедение. - 2004. - Т. 98. - № 4. - С. $11-21$.

11. Попов В. В. Анализ растворимости карбидов, нитридов и карбонитридов в сталях методами компьютерной термодинамики II. Растворимость карбидов, нитридов и карбонитридов в системах Fe-V-C, Fe-V-N и Fe-V-C-N / B. В. Попов, И. И. Горбачев // Физика металлов и металловедение. - 2005. - Т. 99. - № 3. - С. 69-82.

12. Горбачев И. И. Анализ растворимости карбидов, нитридов и карбонитридов в сталях методами компьютерной термодинамики. III. Растворимость карбидов, нитридов и карбонитридов в системах Fe-Ti-C, Fe-Ti-N и Fe-Ti-C-N / И. И. Горбачев, В. В. Попов // Физика металлов и металловедение. - 2009. - Т. 108. - № 5. - С. $1-12$.

13. Горбачев И. И. Термодинамическое моделирование системы Fe-V-Nb-C-N на основе CALPHAD-метода / И. И. Горбачев, В. В. Попов // Физика металлов и металловедение. 2011. - Т. 111. - № 5. - С. 518-525.

14. Горбачев И. И. Термодинамическое моделирование карбонитридообразования в сталях СV-N-Ti / И. И. Горбачев, В. В. Попов, А. Ю. Пасынков // Физика металлов и металловедение. - 2012. - Т. 113. - № 10. - С. 1226-1035.

15. Беликов С. Б. О влиянии тантала на критические точки жаропрочных никелевых сплавов / С. Б. Беликов, С. В. Гайдук, В. В. Кононов // Вестник двигателестроения. - 2004. - № 3. - С. 99-102.

16. Гайдук С. В. Особенности влияния тантала на структуру и свойства никелевых сплавов / С. В. Гайдук // Нові матеріали і технології в металургії та машинобудуванні. - 2004. - № 1. - С. $16-19$. 
17. Морозова Г. И. Сбалансированное легирование жаропрочных никелевых сплавов / Г. И. Морозова // Металлы. - 1993. - № 1. - С. 38-41.

18. Морозова Г. И. Компенсация дисбаланса легирования жаропрочных никелевых сплавов / Г. И. Морозова // Металловедение и термическая обработка металлов. - 2012. - № 12. - С. 52-56.

\title{
MODELING OF THERMODYNAMIC PROCESSES FOR THE EVALUATION OF THE INFLUENCE OF TANTALUM ON CRITICAL TEMPERATURES AND THE STRUCTURE OF MULTI-COMPONENT NICKEL SYSTEMS Haiduk S.V., Glotka A.A., Dorogokuplya A.S.
}

\begin{abstract}
Purpose: to investigate the influence of the new tantalum element in the alloy of MMI-3U in the alloying range $(1-5 \%)$ by weight on the critical temperature of phase transformations and the formation of the structure after crystallization in the molded state and after heat treatment. The calculations by the CALPHAD method are presented in the paper, which allow to effectively predict temperature characteristics at the initial stage of the research, as well as to optimize thermal treatment regimes for obtaining a stable structure without preliminary conducting of direct experiments. The results of the calculations of critical temperatures, are well consistent with the experimental data obtained by the DTA method on monocrystalline samples [001] of test melts.

In this paper, comparative results of the influence of tantalum in the ZMI-3U alloy in the studied range of doping (1-5\%) by weight on the critical temperatures of phase transformations and structuring before and after heat treatment are given. At 5.0\% tantalum, the liquid wastewater temperature $\left(\mathrm{t}_{\mathrm{L}}\right)$ is reduced by $26^{\circ} \mathrm{C}$, and the solidus $\left(\mathrm{t}_{\mathrm{S}}\right)$ temperature is reduced only by $14{ }^{\circ} \mathrm{C}$, compared to those temperatures for the MPA-3U alloy without tantalum. At the same time, the temperature $\left(\mathrm{t}_{\mathrm{EVT}}\right)$ of local melting $\left(\gamma+\gamma^{\prime}\right)$ of the eutectic increases by $37^{\circ} \mathrm{C}$.

For a multicomponent system (Ni-13,5Cr-5Co-3,4Al-4,8Ti-7,3W-0,8Mo-0,015B-0,03Y$0,01 \mathrm{La}-0,12 \mathrm{C}$ ) the tantalum content is up to $4,0 \%$ by weight is estimated as positive. An increase in the content of tantalum to $5.0 \%$ by weight leads to a marked decrease in the solidus temperature $\left(\mathrm{t}_{\mathrm{s}}\right)$ below $1280^{\circ} \mathrm{C}$, which is undesirable for casting heat-resistant nickel alloys operating at temperatures up to $1000^{\circ} \mathrm{C}$ and above. The tantalum content of $5.0 \%$ by weight for the tested multicomponent system is evaluated as negative, since tantalum overlays can lead to such undesirable effects as an increase in structural inhomogeneity and a decrease in phase stability due to the release of harmful THCH-phases of adverse morphology, which can lead to a sharp reduction of durability, especially plasticity, and loss of working capacity of the material.

For more efficient carrying out of the first stage of thermal treatment (homogenization), expands it by $\sim 25^{\circ} \mathrm{C}$. The obtained results allow us to conclude that with an increase in the content of tantalum by $1 \%$ by weight for the investigated compositions, the optimum temperature of homogenization $\left(\mathrm{t}_{\mathrm{GOM}}\right.$. ) increases by an average of $15^{\circ} \mathrm{C}$. Without the tantalum, the temperature of the beginning of the dissolution ( $\left.\mathrm{t}_{\text {P.P. }}{ }^{\gamma^{\prime}}\right)$ and the end of the dissolution $\left(\mathrm{t}_{\mathrm{K} . \mathrm{P}^{\prime}}{ }^{\prime}\right)$ of the $\gamma^{\prime}$-phase are in the $(\sim$ $\left.843^{\circ} \mathrm{C}\right)$ and $\left(\sim 1162^{\circ} \mathrm{C}\right)$, respectively, ZMI-3U alloy. These temperatures are gradually increased and for the composition "5" of 5.0\% tantalum make up $\left(\sim 858^{\circ} \mathrm{C}\right)$ and $\left(\sim 1175^{\circ} \mathrm{C}\right)$ respectively, which positively affects the thermal stability of the phase. Tantalum doping positively affects the temperature interval.

Metallurgical investigations have shown that the microstructure of monocrystalline samples of experimental compositions (0-5) obtained by the serial technology with crystallographic orientation (KHO) [001] in the cast state has a typically dendritic structure, which is manifested in the uneven distribution of the particles of the $\gamma$ 'phase, eutectics $\left(\gamma+\gamma^{\prime}\right)$ and carbide phase. In the interdendritic regions, the metastable non-equilibrium eutectics $\left(\gamma+\gamma^{\prime}\right)$ are located, which have a morphology from fan-like to lamellar. After crystallization in the structure of the studied compositions, the formation of carbides of the type $\mathrm{MeC}$ is observed near the large eutectic emitters $\left(\gamma+\gamma^{\prime}\right)$, which partially fill the
\end{abstract}


space between the dendritic branches. Compared to the ZMI-3U-free tantalum alloy, with a content of tantalum 5.0\% (composition of "5"), the volumetric fraction $\left(\mathrm{V} \gamma^{\prime}\right) \gamma^{\prime}$-phase is increased by $8-10 \%$, eutectics $\left(\gamma+\gamma^{\prime}\right)$ by $3-5 \%$. In the cast state, in the structure of the experimental compositions, the particles of the $\gamma^{\prime}$-phase are separated from the $\gamma$-solid solution more evenly and have the correct cubic morphology, except for the composition of "5", where there is a greater structural inhomogeneity.

After conducting two-stage maintenance in the structure of the investigated warehouses, the amount of metastable phases significantly decreases. With an increase in the concentration of tantalum in the ZMI-3U alloy from $1.0 \%$ to $5.0 \%$, by weight, the volume fraction of fine particles of the $\gamma^{\prime}$ phase increases in structure, in comparison with the structure of the ZMI-3U alloy without tantalum. After conducting the first stage of homogenization, in the process of the second degree of homogenization at $\mathrm{t}=1050^{\circ} \mathrm{C}$, the coagulation of non-dissolved $\gamma^{\prime}$-phase particles is observed in the structure of the experimental compositions. At the same time there is an additional allocation of fine particles of the $\gamma^{\prime}$-phase as a result of the growth of the $\gamma$-solid solution, which forms its bimodality (two dimensions). After the second degree of homogenization, the $\gamma$-phase particles lose the correct cubic form. In the heat-treated state, the bimodality of the particles of the $\gamma$-phase in size is formed in the structure of the experimental compositions. After the two-stage homogenization in the structure of the experimental compositions, the amount of metastable phases is significantly reduced, and a more homogeneous and stable structure is formed.

\section{References}

1. Kablov, Ye. N. (2006). Liteynyye zharoprochnyye splavy. Effekt S. T. Kishkina : nauch.-tekhn. sb. : $k$ 100-letiyu so dnya rozhdeniya S. T. Kishkina [Foundry high-temperature alloys. Effect S. T. Kishkina: scientific-technical. Sat : to the 100th anniversary of the birth of S. T. Kishkin]. - M. : Nauka [in Russian].

2. Kablov, Ye. N. (2001). Lityye lopatki gazoturbinnykh dvigateley (splavy, tekhnologiya, pokrytiya) / Ye. N. Kablov. - Vserossiyskiy nauchno-issledovatel'skiy institut aviatsionnykh materialov, Gosudarstvennyy nauchnyy tsentr Rossiyskoy Federatsii [Cast blades of gas turbine engines (alloys, technology, coatings)]. - M. : MISIS [in Russian].

3. Paton, B. Ye., Stroganov, G. B., Kishkin, S. T. et al. (1987). Zharoprochnost' liteynykh nikelevykh splavov $i$ zashchita ikh ot okisleniya [Heat resistance of cast nickel alloys and their protection against oxidation]. - K. : Nauk. Dumka [in Ukraine].

4. Kishkin, S. T., Stroganov, G. B., Logunov, A. V. (1987). Liteynyye zharoprochnyye splavy na nikelevoy osnove [Casting heat-resistant alloys on a nickel basis]. - M. : Mashinostroyeniye [in Russian].

5. Kotsoradis, D., Feliks P., Fishmayster Kh. Et al. (1981). Zharoprochnyye splavy dlya gazovykh turbin. Materialy mezhdunarodnoy konferentsii [High temperature alloys for gas turbines. International materials conferences]. - M. : Metallurgiya [in Russian].

6. Sims, Ch. T., Stoloff, N. S., Khagel', U. K. (1995). Supersplavy II. Zharoprochnyye materialy dlya aerokosmicheskikh i promyshlennykh energoustanovok [Superalloys II. Heat-resistant materials for aerospace and industrial power plants]. - M. : Metallurgiya [in Russian].

7. Saunders N., Fahrmann, M., Small, C. J. (2000). The Application of CALPHAD Calculations to Ni-Based Superalloys / In «Superalloys 2000» eds. K.A. Green, T. M. Pollock and R.D. Kissinger. - TMS. - Warrendale . - p. 803 [in USA].

8. Fippen J. S., Sparks, P. B. (1979). Using differential thermal analysis to determine phase change temperatures / Metal Progr. - № 4. - P. 56-59 [in USA].

9. Vertogradskiy, V. A., Rykova T. P. (1984). Issledovaniye fazovykh prevrashcheniy v splavakh tipa ZHS metodom DTA [Heat-resistant and heat-resistant steel and alloys on nickel base]. - M. : Nauka [in Russian].

10.Popov, V. V., Gorbachev, I. I. (2004). Analiz rastvorimosti karbidov, nitridov i karbonitridov v stalyakh metodami komp'yuternoy termodinamiki. I. Opisaniye termodinamicheskikh svoystv. Metod rascheta [Metal Physics and Metallography]. - T. 98. - № 4. - S. 11-21 [in Russian].

11.Gorbachev, I. I. Popov, V. V. (2009). Analiz rastvorimosti karbidov, nitridov $i$ karbonitridov $v$ stalyakh metodami komp'yuternoy termodinamiki. III. Rastvorimost' karbidov, nitridov $i$ 
karbonitridov v sistemakh Fe-Ti-C, Fe-Ti-N i Fe-Ti-C-N [Metal Physics and Metallography]. T. 108. - № 5. - S. 1- 12 [in Russian].

12.Gorbachev, I. I., Popov, V. V. (2009). Analiz rastvorimosti karbidov, nitridov $i$ karbonitridov $v$ stalyakh metodami komp'yuternoy termodinamiki. III. Rastvorimost' karbidov, nitridov $i$ karbonitridov v sistemakh Fe-Ti-C, Fe-Ti-N i Fe-Ti-C-N [Metal Physics and Metallography]. T. 108. - № 5. - S. 1- 12 [in Russian].

13. Gorbachev I. I., Popov, V. V. (2011). Termodinamicheskoye modelirovaniye sistemy $\mathrm{Fe}-\mathrm{V}-\mathrm{Nb}-\mathrm{C}-\mathrm{N}$ na osnove CALPHAD-metoda [Metal Physics and Metallography]. - T. 111. - № 5. - S. 518-525 [in Russian].

14.Gorbachev, I. I., Popov, V. V., Pasynkov, A. Yu. (2012). Termodinamicheskoye modelirovaniye karbonitridoobrazovaniya $v$ stalyakh $\mathrm{S}-\mathrm{V}-\mathrm{N}-\mathrm{Ti}$ [Metal Physics and Metallography]. - 2012. $-\mathrm{T}$. 113. - № 10. - S. 1226-1035 [in Russian].

15.Belikov, S. B., Gayduk, S. V., Kononov, V. V. (2004). O vliyanii tantala na kriticheskiye tochki zharoprochnykh nikelevykh splavov [Engine Building Bulletin]. - № 3. - S. 99-102 [in Ukraine].

16. Hayduk, S. V. (2004). Osobennosty vlyyanyya tantala na strukturu y svoystva nykelevykh splavov [New materials and technologies in the metal industry and machine-based machines ]. - № 1. S. 16-19 [in Ukraine].

17.Morozova, G. I. (1993). Sbalansirovannoye legirovaniye zharoprochnykh nikelevykh splavov [Metals]. - № 1. - S. 38-41 [in Russian].

18.Morozova, G. I. (2012). Kompensatsiya disbalansa legirovaniya zharoprochnykh nikelevykh splavov [Metal science and heat treatment of metals]. - № 12. - S. 52-56 [in Russian]. 